\title{
The Obesity Epidemic Is a Worldwide Phenomenon
}

\author{
Barry M. Popkin, Ph.D., and Colleen M. Doak, M.A.
}

\begin{abstract}
Obesity is not just a disease of developed nations. Obesity levels in some lower-income and transitional countries are as high as or higher than those reported for the United States and other developed countries, and those levels are increasing rapidly. Shifts in diet and activity are consistent with these changes, but little systematic work has been done to understand all the factors contributing to these high levels. The goal of this review is to provide an understanding of the patterns and trends of obesity around the world and some of the major forces affecting these trends. Several nationally representative and nationwide surveys are discussed.
\end{abstract}

\section{Introduction}

It is widely acknowledged that obesity has emerged as an epidemic in developed countries during the last quarter of the 20th century. It continues to be an issue of great concern. In addition, we now face the emergence of obesity as a worldwide phenomenon, affecting wealthy and middleincome people alike in middle-income countries, as well as residents of countries previously considered to be poor. Obesity is excessive enough to cause many to define this as an obesity epidemic. ' From a nutrition perspective, research and policy in countries such as China, Brazil, and many lower-income countries have focused on problems of undernutrition, but we present information here to point to an emerging paradigm of either a dominant problem of obesity or an ever-increasing obesity problem. Elsewhere we have shown that for China this increasing trend in adult obesity may coexist with an increase in chronic energy deficiency among adults. ${ }^{2}$

Several case studies using smaller, focused samples have elucidated the complications of obesity and associated chronic diseases, such as cardiovascular diseases, in adults. These diseases represent far too great a burden for researchers, health experts, and policy makers to ig-

Dr. Popkin and Ms. Doak are with the Department of Nutrition, University of North Carolina at Chapel Hill, Chapel Hill, NC 27516-3997, USA. nore in places such as Brazil, Cuba, Egypt, South Africa, Thailand, and Vietnam. ${ }^{3-15}$ There is extensive documentation of populations in these countries with high energy and fat intakes and above-average levels of obesity among adults. There are equally important problems emerging among children and adolescents in lower-income countries, ${ }^{16}$ but the focus of this review is adults; insufficient data on adolescents preclude their use in this article.

It is important to gain an understanding of the factors that are contributing to this worldwide trend. Because so many populations in a wide range of environments have witnessed a large increase in the proportion of obese children and adults, some comprehension of the role of key underlying behaviors is important. The major factors implicated in the West have been the modern food supply and ready availability of high-fat foods for at-home and away-from-home consumption, along with marked shifts in physical activity patterns at work and during recreation. Large nationwide surveys provide some sense of not only body composition patterns but also some of the key underlying shifts in diet and physical activity patterns.

\section{Study Methods}

\section{Survey Designs and Samples}

Data come from several sources. Analyses discussed in this article that have not been published elsewhere are based on Chinese and Russian surveys. The China Health and Nutrition Survey (CHNS), an ongoing, longitudinal survey of eight provinces in China, is reviewed in detail. A multistage, random, cluster sampling procedure was used to draw a sample from each province. Additional detail on the research design of this survey is presented elsewhere. ${ }^{17}$ Other data sets are from the Russian Longitudinal Monitoring Survey (RLMS), ${ }^{18,19}$ the first nationally representative sample of the Russian Federation. Data collection is identical with that for the China survey, except that in China doctors and nutritionists collected all data, whereas in Russia trained nonmedical interview specialists collected the data.

Additional data from published surveys conducted in all regions of the world are also discussed. The main 
focus is on larger and more representative samples of adults. Selection criteria for presenting data from other surveys were size, sampling design, and geographic area. If a study was representative of a region or country, it was always used. If it came from a country with few studies and did not fit our criteria of national representativeness, we used it if the sample size was large and it seemed reasonably representative of the population being sampled. Because there are few studies of trends in obesity, those that provide reasonably comparable measurement and sampling criteria were always selected.

\section{Measures}

Body mass index (BMI, measured in $\mathrm{kg} / \mathrm{m}^{2}$ ) is the standard population-based measure of overweight and obesity status. For adults, the cutoffs used to delineate obesity are: < 18.5 for thinness (chronic energy deficiency), 18.5-24.99 for normal, 25.0-29.99 for overweight grade I, 30.0-39.99 for overweight grade II, and $\geq 40.0$ for overweight grade III. ${ }^{20}$ For the purposes of this review, grades II and III are combined. Ideally, we would follow these cutoffs universally, but unfortunately, many published results uise lower cutoffs (e.g., many define a BMI of $>25$ as grade I, whereas others use the National Center for Health Statistics percentile cutoffs of 27.8 for males and 27.3 for females). The data sets are unavailable for revision.

\section{Results}

\section{Higher-Income Countries}

As background, it is useful to present trends for adult obesity in countries for which we have good comparable measures: the United States, Finland, England, Germany, and Australia. Table $1^{21-29}$ summarizes data on the patterns and trends of adult obesity in these countries. The United States, Germany, and Finland have the highest levels of grade II overweight. Italy appears to have the highest level of grade I overweight. ${ }^{29}$ Grade I overweight is not presented for any other high-income countries. The level of obesity and the rate of change per year over a longer period of time are highest in the United States and England. The U.S. trend reflects a major increase in obesity during the last decade. ${ }^{21,22}$

\section{Lower- and Middle-Income Countries}

Prevalence. Before trends in these countries are explored, some sense of current knowledge on the prevalence of obesity should be discussed. Data from nationally representative surveys from a range of middle- and lower-income countries are available, as are large surveys from selected population groups in other countries. Both sets of results appear in Table $2,4,6,12,30-45$ in which three measures of obesity-grade I, grades II and above, and grades I and above-are shown. The highest levels of obesity (grade II and above) occur in the Middle East, Western Pacific, and Latin America.

Latin America. When we focus on obesity measures of grades I and II and above for Latin America, we find that more than $10 \%$ of females are obese in Brazil and Colombia, more than $50 \%$ of the population is overweight (grade I) in Mexico, and more than $30 \%$ are overweight in Peru. The range is lower in other South American countries. Several of these South American examples come from urban samples only. In all three countries, where we have

Table 1. Trends in Adult Obesity in High-Income Countries

\begin{tabular}{|c|c|c|c|c|c|}
\hline & Reference & Time Period & Obesity Trend (\%) & $\begin{array}{l}\text { BMI Cutoff } \\
\left(\mathrm{kg} / \mathbf{m}^{2}\right)\end{array}$ & Characteristics \\
\hline United States & 21,22 & 1960-1994 & & & Nationally representative sample \\
\hline Men & & & $23.0-33.3$ & 27.8 & \\
\hline $\begin{array}{l}\text { Women } \\
\text { Enoland }\end{array}$ & & & $23.6-34.9$ & 27.3 & \\
\hline England & 23,62 & 1980-1994 & & & Nationally representative sample \\
\hline $\begin{array}{l}\text { Men } \\
\text { Women }\end{array}$ & & & $\begin{array}{l}6-15 \\
8-16\end{array}$ & $>30$ & \\
\hline Sweden & 24,25 & $1980 / 1-1988 / 9$ & & & Nationally representative sample \\
\hline $\begin{array}{l}\text { Men } \\
\text { Women }\end{array}$ & & & $\begin{array}{l}4.9-5.3 \\
8.7-9.1\end{array}$ & $\begin{array}{c}>30 \\
>28.6\end{array}$ & \\
\hline Germany & 26 & $1985-1990$ & & & Nationally representative sample \\
\hline $\begin{array}{l}\text { Men } \\
\text { Women }\end{array}$ & & & $\begin{array}{l}14.1-17.2 \\
16.5-19.3\end{array}$ & $>30$ & \\
\hline Finland & 27 & $1972-1992$ & & & Regionally representative sample \\
\hline $\begin{array}{l}\text { Men } \\
\text { Women }\end{array}$ & & & $\begin{array}{l}11-21 \\
22-18\end{array}$ & $>30$ & \\
\hline Australia & 28 & $1980-1989$ & & & Random, six cities \\
\hline $\begin{array}{l}\text { Men } \\
\text { Women }\end{array}$ & & & $\begin{array}{l}9.3-11.5 \\
8.0-13.2\end{array}$ & $>30$ & \\
\hline $\begin{array}{l}\text { Italy } \\
\text { Men } \\
\text { Women }\end{array}$ & 29 & $1983-1994$ & $\begin{array}{l}41.2-46.1 \\
28.9-31.3\end{array}$ & $\geq 25$ & Nationally representative sample \\
\hline
\end{tabular}


Table 2. Obesity Patterns in Adults in Lower- and Middle-Income Countries: Studies with Large Sample Sizes

\begin{tabular}{|c|c|c|c|c|c|c|c|}
\hline \multirow[b]{2}{*}{ Country } & \multirow[b]{2}{*}{ Year } & \multirow[b]{2}{*}{ Sample (n) } & \multirow{2}{*}{$\begin{array}{c}\text { Obesity } \\
\text { Criterion } \\
\text { (BMI) }\end{array}$} & \multirow[b]{2}{*}{$\begin{array}{c}\text { Age Group } \\
\text { (years) }\end{array}$} & \multicolumn{3}{|c|}{$\%$ Obese } \\
\hline & & & & & Males & Females & Total \\
\hline \multicolumn{8}{|l|}{ Latin America } \\
\hline Brazil $^{12}$ & 1989 & 23,544 & $>30$ & $25-64$ & 5.9 & 13.3 & 9.6 \\
\hline \multirow{2}{*}{ Peru $^{30}$} & $1975 / 76$ & 3145 & $\geq 25$ & Adults & - & - & 33.8 \\
\hline & $1975 / 76$ & 3145 & $>30$ & Adults & - & - & 9.0 \\
\hline Colombia $^{31}$ & $1988-89$ & 1572 & $\geq 27.3$ & $18-44$ & - & 11.1 & - \\
\hline \multirow[t]{2}{*}{ Mexico $^{32}$} & 1995 & $2042(U)$ & $\geq 25$ & Adults & 50.0 & 58.0 & - \\
\hline & 1995 & 2042(U) & $\geq 30$ & Adults & 11.0 & 23.0 & - \\
\hline \multicolumn{8}{|l|}{ Caribbean } \\
\hline \multirow[t]{3}{*}{$\mathrm{Cuba}^{4}$} & 1982 & 30,063 & $\geq 25$ & $20-59$ & 31.5 & 39.4 & 36.4 \\
\hline & 1982 & $20,539(\mathrm{U})$ & $\geq 25$ & $20-59$ & 36.0 & 41.8 & 39.7 \\
\hline & 1982 & $9513(\mathrm{R})$ & $\geq 25$ & $20-59$ & 22.6 & 33.9 & 29.4 \\
\hline \multicolumn{8}{|l|}{ Asia } \\
\hline \multirow[t]{3}{*}{ China $^{33}$} & 1992 & 54,006 & $>25$ & $>20$ & 11.9 & 17.0 & 14.6 \\
\hline & 1992 & $18,472(U)$ & $>25$ & $>20$ & 20.8 & 25.1 & 23.1 \\
\hline & 1992 & $35,534(\mathrm{R})$ & $>25$ & $>20$ & 7.4 & 12.7 & 10.2 \\
\hline \multirow[t]{2}{*}{ Kyrgystan } & 1993 & 4053 & $\geq 30$ & $18-59$ & 4.2 & 10.7 & - \\
\hline & 1993 & 4053 & $25-30$ & $18-59$ & 26.4 & 24.3 & - \\
\hline \multirow{2}{*}{ India $^{30}$} & $1988 / 90$ & 21,361 & $\geq 25$ & Adults & - & - & 3.5 \\
\hline & $1988 / 90$ & 21,361 & $>30$ & Adults & - & - & 0.5 \\
\hline \multirow[t]{2}{*}{ India $^{34}$} & 1994 & 1832 & $>25$ & $12-47$ & - & 6.6 & - \\
\hline & $1993-94$ & 1319 (U, slum) & $>25$ & $12-47$ & - & 11.6 & - \\
\hline \multirow[t]{2}{*}{ Thailand $^{15}$} & 1985 & $3495(\mathrm{U})$ & $\geq 25$ & $35-54$ & 25.5 & 21.4 & 24.6 \\
\hline & 1985 & $3493(U)$ & $\geq 30$ & $35-54$ & 2.2 & 3.0 & 2.4 \\
\hline Philippines $^{35}$ & 1993 & 9585 & $>30$ & $\geq 20$ & 1.7 & 3.4 & - \\
\hline & 1993 & 9585 & $25-30$ & $\geq 20$ & 11.0 & 11.8 & - \\
\hline Malaysia $^{36}$ & 1990 & 4747 & $>25-30$ & $18-64$ & 24.0 & 18.1 & 21.4 \\
\hline & 1990 & 4747 & $>30$ & $18-64$ & 4.7 & 7.9 & -6.1 \\
\hline West Pacific & & & & & & & \\
\hline Nauru $^{37}$ & 1994 & 1344 & $>30$ & $25-69$ & 80.2 & 78.6 & 79.4 \\
\hline New Caledonia ${ }^{38}$ & $1992-94$ & $6503(\mathrm{R})$ & $\begin{array}{l}\geq 25 \text { (F) } \\
\geq 27 \text { (M) }\end{array}$ & $30-59$ & 44.6 & 71.4 & 59.0 \\
\hline & $1992-94$ & $641(U)$ & $\begin{array}{l}\geq 25 \text { (F) } \\
\geq 27 \text { (M) }\end{array}$ & $30-59$ & 59.1 & 79.6 & 72.7 \\
\hline North Africa/Middle East & & & & & & & \\
\hline Kuwait $^{39}$ & $1993-94$ & 3435 & $>30$ & $\geq 18$ & 32.3 & 40.6 & 36.4 \\
\hline & $1993-94$ & 3435 & $>25-30$ & $\geq 18$ & 35.2 & 32.3 & 33.8 \\
\hline Saudi Arabia ${ }^{40}$ & 1996 & 13,177 & $>30$ & $15-95$ & 16.0 & 24.0 & 19.8 \\
\hline & 1996 & 13,177 & $25-30$ & $15-95$ & 29.0 & 27.0 & 28.0 \\
\hline Egypt $^{41}$ & $1993-94$ & 5812 & $25<\mathrm{BMK}<30$ & $>15$ & - & 36.8 & - \\
\hline & $1993-94$ & 5812 & $>30$ & $>15$ & - & 35.1 & - \\
\hline Morocco ${ }^{42}$ & $1984-85$ & National $^{a}$ & $\geq 30$ & $>20$ & 2.3 & 14.6 & 8.7 \\
\hline & 1984.85 & Urban $^{\mathrm{a}}$ & $\geq 30$ & $>20$ & 2.9 & 19.7 & 11.9 \\
\hline & $1984-85$ & Rurala & $\geq 30$ & $>20$ & 1.9 & 10.3 & 6.3 \\
\hline Tunisia $^{30}$ & 1990 & 8611 & $>30$ & Adults & 2.4 & 8.3 & 5.3 \\
\hline & 1990 & 8611 & $\geq 25$ & Adults & 20.0 & 32.7 & 26.3 \\
\hline Sub-Saharan Africa & & & & & & & \\
\hline Congo $^{30}$ & $1986 / 87$ & 2295 & $\geq 25$ & $>18$ & - & 15.2 & - \\
\hline & $1986 / 87$ & 2295 & $>30$ & $>18$ & - & 3.4 & - \\
\hline Congo $^{6}$ & 1991 & $3004(U)$ & $>25$ & $\geq 18$ & - & - & 23.6 \\
\hline & 1992 & $1344(\mathrm{R})$ & $>25$ & $\geq 18$ & - & - & 4.1 \\
\hline Mali $^{30}$ & 1991 & 4868 & $\geq 25$ & Adults & - & - & 7.2 \\
\hline & 1991 & 4868 & $>30$ & Adults & - & - & 0.8 \\
\hline South Africa ${ }^{43}$ & 1979 & 7187 & $>30$ & $15-64$ & 14.7 & 18.0 & 16.5 \\
\hline & 1979 & 7187 & $\begin{array}{l}\geq 25-30(\mathrm{M}) \\
\geq 24-30(\mathrm{~F})\end{array}$ & $15-64$ & 41.9 & 38.8 & 40.3 \\
\hline South Africa ${ }^{44}$ & 1990 & $986(\mathrm{Bl})$ & $\geq 30$ & $15-64$ & 7.9 & 44.4 & 28.0 \\
\hline Mauritius $^{45}$ & 1992 & 5111 & $>30$ & $25-74$ & 5.3 & 15.1 & 10.6 \\
\hline & 1992 & 5111 & $>25$ & $25-74$ & 35.7 & 47.7 & 42.2 \\
\hline
\end{tabular}

Note: $\mathrm{U}=$ urban, $\mathrm{R}=$ rural, $\mathrm{F}=$ female, $\mathrm{M}=$ male, $\mathrm{Bl}=$ black. Obesity $(\mathrm{BMI} \geq 30.0)$ and overweight $(\mathrm{BMI}=25.0-29.99)$ are based on classifications of the National Center for Health Statistics.

${ }^{a}$ The sample sizes for Morocco are unclear. They are either 41,921 or $10,445,034$. 
gender-specific data, women have higher levels of overweight and obesity than men. Few data are available in terms of large-scale surveys in the Caribbean; however, other studies and the Cuban data presented here indicate that the Caribbean nations have high levels of obesity. ${ }^{46}$ The Caribbean countries for which there is information are split $50 / 50$ between high versus moderate obesity prevalence. Cuba and Barbados have a higher prevalence $(>20 \%)$, but Jamaica and St. Lucia have only about $12-$ $15 \%$ obesity.

Asia. There is very little grade II and above obesity in Asia, and most countries have levels in the 5-15\% range for grade I. The documented exceptions are urban China, urban Thailand, Malaysia, and the Central Asian countries, such as Kyrgyzstan, that were members of the Soviet Union before 1992. There is no clear gender pattern to obesity levels in Asia. The prevalence of obesity in Malaysia and urban Thailand may be related to a relatively higher level of economic development.

Western Pacific. The high rates of obesity and related chronic diseases in the island nations of Samoa and Nauru, Fiji, and Melanesia (the latter two are not represented in the tables) have been the subject of many studies. Nearly half the population in this region has grade II or above obesity. In most cases, female obesity is much more prevalent.

Middle East. Although data are limited, it appears that more than a third of the adult population in oil-exporting countries such as Kuwait and Saudi Arabia are overweight or obese. In the North African countries, the situation reflects an emerging problem, with considerable grade I overweight but with less grade II and above.
Again, female obesity is higher in all countries for which data are available for both genders.

Sub-Saharan Africa. Aside from Mauritius, there are no nationally representative surveys in sub-Saharan Africa. The scattered data from South Africa, Mali, and the Congo indicate high levels of obesity in urban sub-Saharan Africa. There are few data for rural areas, but what information does exist shows a minimal problem. South Africa might be the exception: limited studies on Africans, particularly women, indicate the possibility of high levels of obesity in both urban and rural areas. ${ }^{47}$

\section{Trends}

Data on trends in body composition are excellent for a small number of lower- and middle-income countries. There are nationally representative or large nationwide data sets for Brazil (Latin America), China and India (Asia), Mauritius (Africa), Nauru and Western Samoa (South Pacific), and Russia. These provide some sense of trends in adult obesity (Table $3^{12,32-34,37,39,45,48-50}$ and Figure 1). In Figure 1, all of the trends are converted into percentage-point increases during a 10 -year period.

Brazil. The trends in Brazil are presented in detail elsewhere..$^{12}$ During a 15 -year period, the proportion of grade II and above overweight adult males almost doubled (5.7-9.6\%). For females of reproductive age, there are data over a 21 -year period..$^{48}$ The proportion of grade II obesity increased by $230 \%$. Interestingly, the ratio between the underweight and overweight prevalence-a measure of the relative importance of each problem in the population-changed dramatically between 1974 and 1989. In the case of all adults, the ratio was even reversed: in 1974,

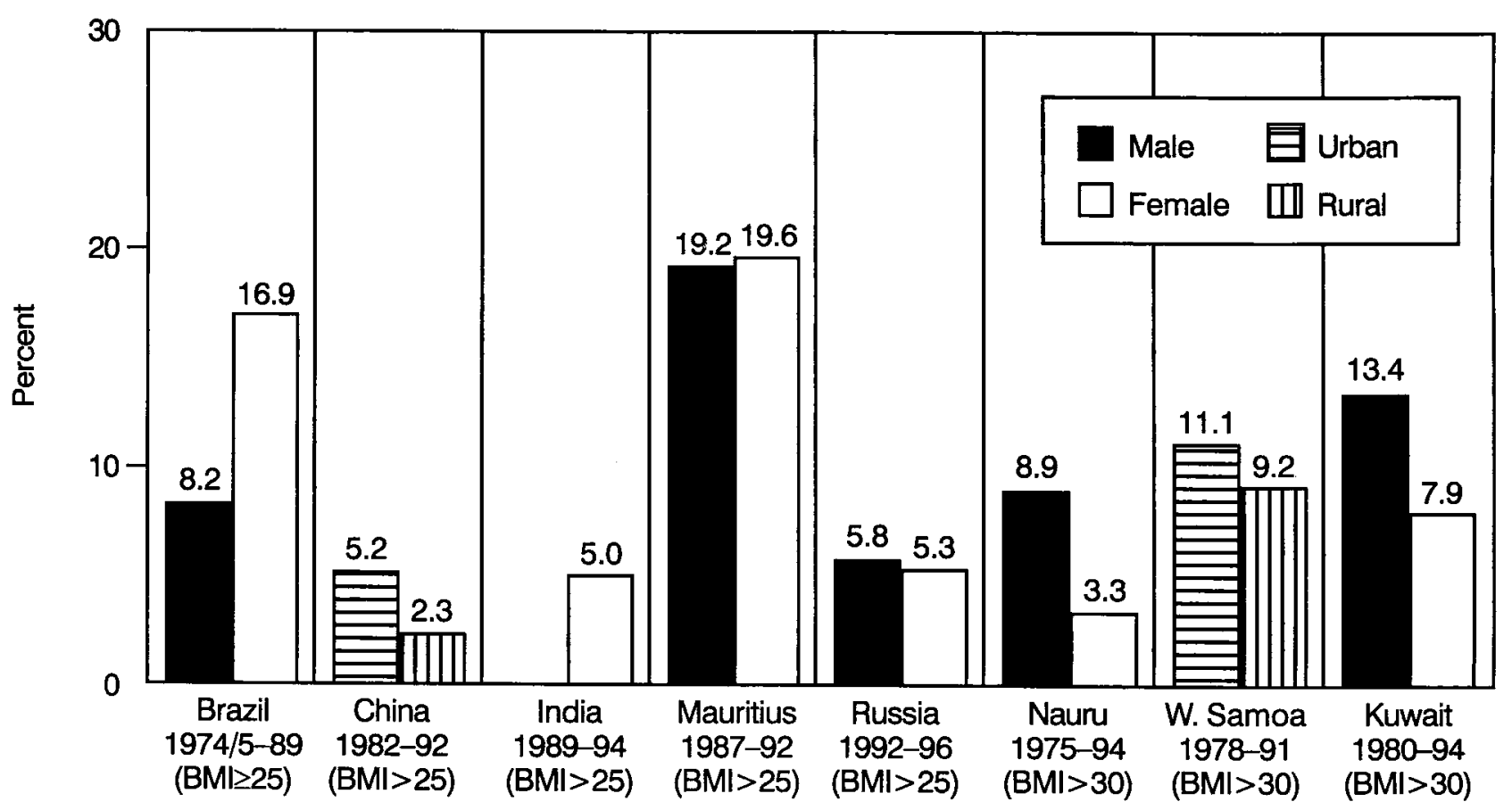

Figure 1. Obesity trends: the percentage-point increase in obesity prevalence per 10-year period. 
Table 3. Obesity Trends in Adults in Lower-and Middle-Income Countries

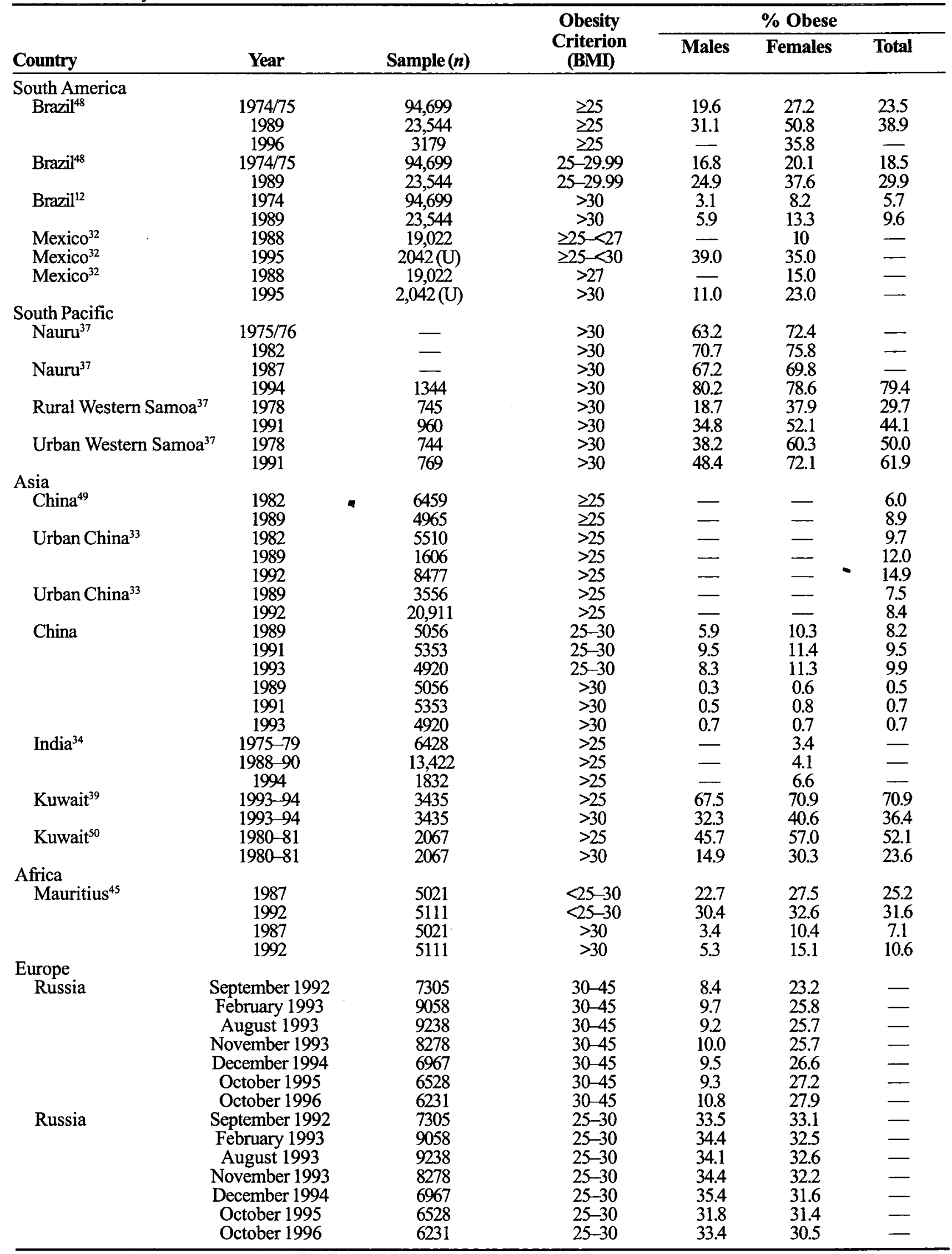

Note: $U=$ urban. 
the underweight:overweight ratio was 1.5 , whereas in 1989 , the overweight:underweight ratio was more than 2 . These increases in overweight occur for all income strata and in both sexes, but the proportional increases are largest among the poorest families. ${ }^{12}$

China. Shifts in diet, physical activity, and overweight status in China are among the most rapid ever documented. Among school-age children, Chinese obesity rates are rapidly reaching levels comparable to those in the United States, although this is not the case for adults. ${ }^{16}$ The level of overweight in Chinese adults remains low, but the marked shifts in diet and activity and grade I overweight lead one to believe that major increases in grades I and II overweight will occur. These recent changes are rapid in urban residents of all incomes but even more rapid in middleand higher-income rural residents. ${ }^{51}$ The rate of increase is highest in the lowest-tertile segments of both urban and rural populations. Although national nutrition surveys in China from 1982 to 1992 indicate a moderate rate of increase, this hides the more rapid shifts in diet, activity, and obesity seen in the last few years. ${ }^{33,49}$ During the most recent period, the CHNS (1989-1993) data sthow a consistent increase in adult obesity in urban and rural areas.

India. Much less information is available for India, where data are available only for women of childbearing age. During the 19 years between 1975-1994 a small weight increase was observed, but a more rapid rate of increase occurred for women from 1989 to 1994.

Kuwait. In 1980-1981, the prevalence of grade I overweight and above was more than $50 \%$ for females and nearly as high for males. This rose to approximately $70 \%$ for both males and females by 1994 , indicating a 14.5 percentage-point increase per decade. Grade II obesity increased by a total of $12.8 \%$, representing a per-decade percentage-point increase of $9.8 \%$.

Mauritius. This small island republic has a very high prevalence of non-insulin-dependent diabetes mellitus (NIDDM), ${ }^{45}$ a disease frequently related to obesity. A rapid increase in obesity is occurring in both males and females. In particular, the increase in female grade II and higher obesity is greater than that found in many high-income countries. During a 5-year period (1987-1992), there were marked increases in grade I and II obesity.

Russia. Russia has one of the highest rates of mortality related to coronary heart disease (CHD) in the world. Despite marked shifts toward a lower-fat diet in the postreform period, during which price subsidies of meat and dairy products were removed, there is evidence of an increase in adult obesity. Data for seven rounds of the nationally representative Russian Longitudinal Monitoring Survey find a consistent increase in adult and elderly obesity. ${ }^{19}$ It is remarkable that the effects of the economic reform-induced dietary changes have not been linked with meaningful changes in obesity patterns. Prevalence of grade I overweight in females shows a consistent decline between 1992 and 1996, whereas in males there is virtually no difference. The survey shows an overall increase in grade II obesity for both males and females and an increase in total obesity of more than five percentage points per 10-year period for Russia. Despite the overall increase in obesity, year-to-year fluctuations underscore the fact that the economy is in flux and that these changes cannot be used to predict future trends.

Western Pacific. A large body of literature documents high rates of obesity, in particular grade III and above, in populations of the western Pacific islands. Modernization has been associated with a very high prevalence of obesity in the West and South Pacific islands, particularly among urban residents. ${ }^{52-54}$ In those islands (e.g., Fiji, Kiribati, Nauru, American and Western Samoa, and the Republic of Vanuatu), high rates of severe obesity mirror the rates found among Native American groups in the United States. ${ }^{55}$ The trends reported in the studies of Hodge et al..$^{52,53}$ indicate that obesity levels are not only high, but that the prevalence of obesity continues to increase considerably in each island. In Nauru and Western Samoa, the levels of grade I and II obesity are among the highest in the world and are increasing steadily.

\section{Related Shifts in Diet and Activity}

There is little to suggest that this trend of rapidly increasing obesity rates in lower- and middle-income countries will not continue unabated over the next several decades. Information on the effects of rapid changes in urbanization and the structure of work and income on obesity rates is presented elsewhere. ${ }^{56}$ Significant links between these dietary and activity changes and increased obesity in China are discussed elsewhere. ${ }^{57-59}$

The major shifts in diet that seem to be occurring on a worldwide basis in lower-income countries include a large increase in the consumption of vegetable oils, a shift away from coarser grains to more refined ones, and a shift toward a more diverse diet that includes more meats and eggs. As many studies have shown, dietary diversity is a positive shift and with it has come a remarkable decline in undernutrition in many regions of the world. ${ }^{12}$ The types of changes in activity and the causes for the changes vary by age. Among adults, there is a vast shift in the structure of employment, with a movement toward more capital-intensive and knowledge-based employment that relies far less on physical activity. ${ }^{56}$ Figure 2 shows the shift in the structure of employment that has been occurring in lower-income countries during the past several decades. This shift is most profound in its rapidity and its impact on energy expenditures for adults. In China, we have studied this shift in adults and have found that the rapid decline in physical activity at work in urban areas is significantly associated with increased adult BMI measures and obesity. ${ }^{59}$ 


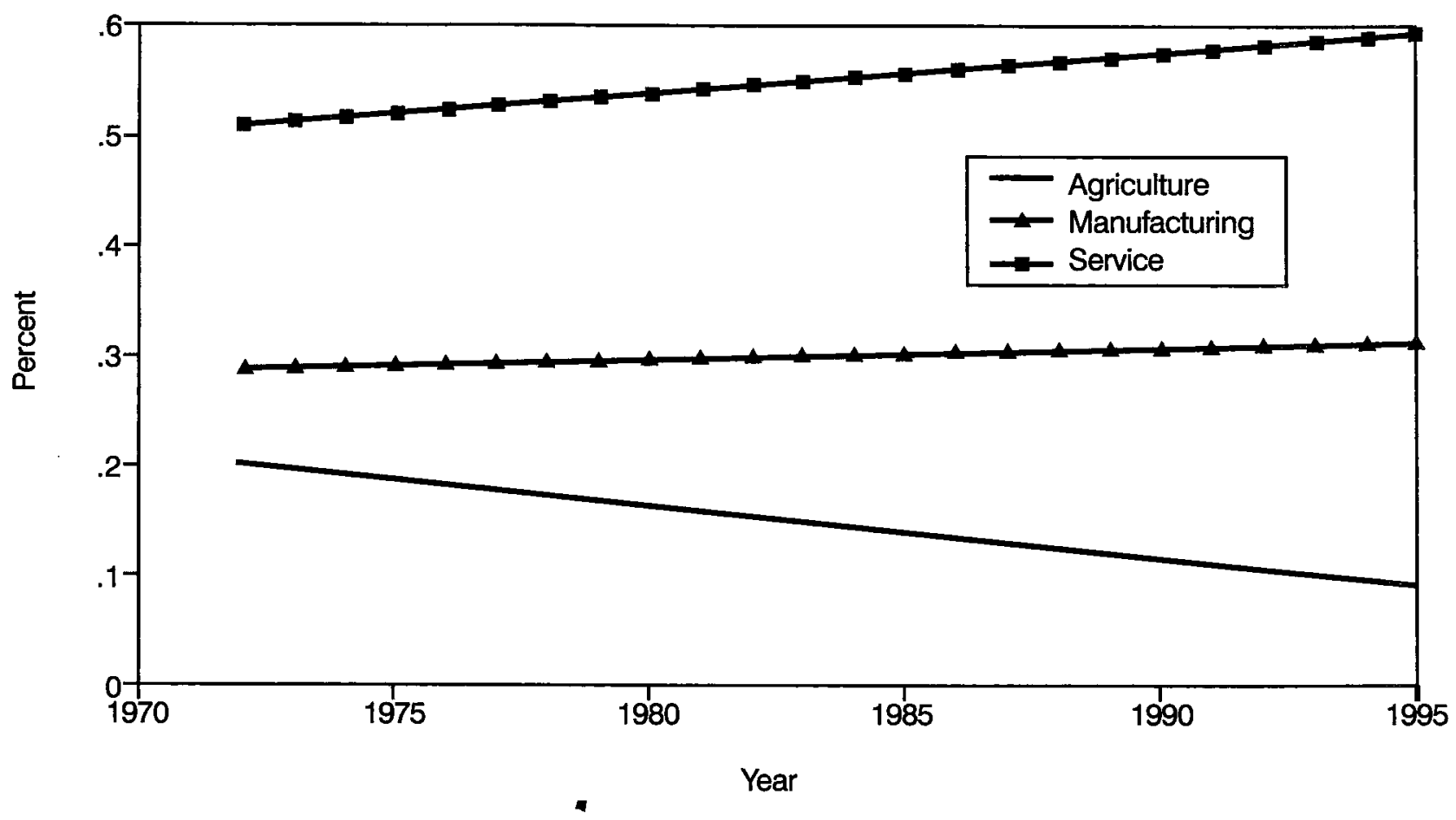

Figure 2. Shifts in the distribution of occupations for lower-income countries, 1972-1993.

We have also observed large shifts toward much less physically demanding occupations on a worldwide basis, and this trend continues. This shift is reflected not only in the proportion of people working in agriculture, industry, and services, but also in the type of work within most occupations. The shift in activity is also found in the increased use of transportation to get to work or school, more technology in the home, and far more passive leisure time. Rapid urbanization, which is occurring at much lower income levels than has heretofore been experienced, is one critical underlying cause of increased rates of obesity. ${ }^{57,60} \mathrm{High}$ rates of urbanization continue, as do increasingly rapid shifts in the structure of occupations and the introduction of many new technologies that facilitate inactivity among all age groups. ${ }^{56}$

\section{Research and Policy Implications}

Foremost, we must recognize that these changes in diet, activity, and obesity are increasingly linked with rapid increases in NIDDM and CHD in many lower-income countries. $^{61}$

There is ample indication that trends in obesity are not limited to one region, country, or racial/ethnic grouping. The overall increased levels found in selected countries such as Mexico, South Africa, Malaysia, and nations of the Western Pacific are indicative of major public health problems. That these changes appear to be occurring across so many countries lends weight to the need to understand the underlying environmental causes, rather than focusing attention solely on genetic causes of obe- sity. It also opens up the possibility that international studies can help clarify the causes of these patterns.

Clearly, excess body fat develops when dietary energy intake exceeds energy expenditure. Diet and physical activity are major proximate determinants of obesity, which may be shared across all populations. The relative contribution of metabolic differences, inactivity, and dietary energy and fat intakes in each population is unknown. More particularly, cross-national studies provide insights into the types of programs and policies that affect physical activity and dietary change. Although there will be large differences in the underlying socioeconomic and behavioral factors related to obesity in each country, the policies and programs that alter these patterns may be best understood by examining settings around the world.

Policy makers must give the development of approaches to prevent obesity a higher priority. Few countries, aside from higher-income ones, are devoting resources to treat or even understand the nature of the problem. Before the world's medical systems are swamped by an epidemic of non-insulin-dependent diabetes and coronary heart disease, preventive action must be taken.

Acknowledgments. Preparation of this article was supported in part by grants from the U.S. National Institutes of Health (R01-HD30880). The authors thank the following staff of the Carolina Population Center, University of North Carolina at Chapel Hill: Tom Swasey for his work on the graphics, Lynn Igoe for editorial assistance, Frances Dancy for administrative assistance, and Soowon Kim for assistance in preparing the tables. They also credit col- 
laborators on the China Health and Nutrition Survey, in particular Drs. Keyou Ge and Fengying Zhai, Institute of Nutrition and Food Hygiene, Chinese Academy of Preventive Medicine; and on the Russian Longitudinal Monitoring Survey, notably Alexander Baturin, Russian Institute of Nutrition, Academy of Medical Sciences.

1. Webster's Third New International Dictionary of the English Language. Chicago: Encyclopedia Britannica, 1966

2. Popkin BM, Paeratakul S, Zhai F, Ge K. Body weight patterns among the Chinese: results from the 1989 and 1991 China Health and Nutrition Surveys. Am J Public Health 1995;85:690-4

3. Beckles GLA, Miller GJ, Alexis SD, et al. Obesity in women in an urban Trinidadian community: prevalence and associated characteristics. Int J Obes Relat Metab Disord 1985;9:127-35

4. Berdasco A. Body mass index values in the Cuban adult population. Eur J Clin Nutr 1994;48(Suppl 3): $5155-64$

5. Chadha SL, Radhakrishnan S, Ramachandran K, et al. Epidemiological study of coronary heart disease in urban population of Delhi. Indian J Med Res 1990;92:424-30

6. Delpeuch F, Cornu A, Massamba J-P, êt al. Is body mass index sensitively related to socio-economic status and to economic adjustment? A case study from the Congo. Eur J Clin Nutr 1994;48(Suppl 3): $\$ 141-7$

7. Duncan BB, Schmidt MI, Achutti AC, et al. Socioeconomic distribution of noncommunicable disease risk factors in urban Brazil: the case of Porto Alegre. Bull Pan Am Health Organ 1993;24:337-49

8. Galal OM, Harrison, GG. Goals for preventive nutrition in developing countries. In: Bendich $A$, Deckelbaum, RJ, eds. Preventive nutrition: the comprehensive guide for health professionals. Totowa, NJ: Humana Press; 1997

9. INCLEN Multicentre Collaborative Group. Risk factors for cardiovascular disease in the developing world: a multicentre collaborative study in the International Clinical Epidemiology Network (INCLEN). $\mathrm{J}$ Clin Epidemiol 1992;45:841-7

10. INCLEN Multicentre Collaborative Group. Socio-economic status and risk factors for cardiovascular disease: a multicentre collaborative study in the International Clinical Epidemiology Network (INCLEN). J Clin Epidemiol 1994;47:1401-9

11. Ladda M-S, Junjana C, Puetpaiboon A. Increasing obesity in school children in a transitional society and the effect of the weight control program. Southeast Asian J Trop Med Public Health 1993;24:590 4

12. Monteiro CA, Mondini L, de Souza ALM, Popkin BM. The nutrition transition in Brazil. Eur $\mathrm{J}$ Clin Nutr 1995;49:105-13

13. Sinha DP, Mclntosh, $C E$. Changing nutritional patterns in the Caribbean and their implications for health. Food Nutr Bull 1992;14(2):88-96

14. Steyn K, Jooste PL, Bourne LT, et al. Risk factors for coronary heart disease in the black population of the Cape Peninsula: the BRISK Study. S Afr Med J 1991;79:480-5
15. Tanphaichitr V, Kulapongse $S$, Pakpeankitvatana $R$, et al. Prevalence of obesity and its associated risks in urban Thais. In: Oomura Y, Tarui S, Inoue S, Shimazu T, eds. Progress in obesity research, 1990. London: Libbey, 1991;649-53

16. Popkin BM, Richards MK, Monteiro, CA. Stunting is associated with overweight in children of four nations that are undergoing the nutrition transition. $J$ Nutr 1996;126:3009-16

17. Popkin BM, Ge K, Zhai F, et al. The nutrition transition in China: a cross-sectional analysis. Eur $\mathrm{J}$ Clin Nutr 1993;47:333-46

18. Mroz T, Popkin, BM. Poverty and the economic transition in the Russian Federation. Econ Devel Cult Change 1995;44:1-31

19. Popkin BM, Zohoori N, Baturin A. The nutritional status of the elderly in Russia, 1992-1994. Am J Public Health 1996;86:355-60

20. WHO Expert Committee. Physical status: the use and interpretation of anthropometry: report of a WHO Expert Committee. Geneva: World Health Organization; 1995. WHO Technical Report Series 854.

21. Kuczmarski RJ, Flegal KM, Campbell, SM, Johnson, CL. Increasing prevalence of overweight among US adults: the National Health and Nutrition Examination Surveys, 1960-1991. JAMA 1994;272:205-11

22. Anon. Update: prevalence of overweight among children, adolescents, and adults: United States, 198894. MMWR Morb Mortal Wkly Rep 1997;46:199-202

23. Anon. The health of the nation: one-year on a report on the progress of the health of the natton. London: Department of Health; 1993

24. Kuskowska-Wolk A, Bergström R. Trends in body mass index and prevalence of obesity in Swedish women, 1980-89. J Epidemiol Community Health 1993;47:195-9

25. Kuskowska-Wolk A, Bergström R. Trends in body mass index and prevalence of obesity in Swedish men, 1980-89. J Epidemiol Community Health 1993;47:103-8

26. Hoffmeister $H$, Mensink GBM, Stolzenberg H. National trends in risk factors for cardiovascular disease in Germany. Prev Med 1994;23:197-205

27. Pietinen $P$, Vartiainen $E$, Männistö $S$. Trends in body mass index and obesity among adults in Finland from 1972-1992. Int J Obes Relat Metab Disord 1996;20:114-20

28. Bennett SA, Magnus P. Trends in cardiovascular risk factors in Australia: results from the National Heart Foundation's Risk Factor Prevalence Study, 19801989. Med J of Australia 1994;161:519-27

29. Pagano $R$, Vecchia $C L$, Decarli $A$, et al. Trends in overweight and obesity among Italian adults, 19831994. Am J Public Health 1997;87(11):1869

30. Shetty PS, James WPT. BMI distribution in developed and developing countries. In: Body mass index: a measure of chronic energy deficiency in adults. Rome: Food and Agriculture Organization of the United Nations; 1994. FAO Food and Nutrition Papers no 56

31. Dufour DL, Staten LK, Reina JC, Spurr GB. Anthropometry and secular changes in stature of urban Colombian women of differing socioeconomic status. Am J Hum Biol 1994;6:749-60

32. Sánchez-Castillo C, Lara JJ, James WPT. Diet and 
nutritional trends in Mexico. In: Proceedings of the International Congress of Nutrition. Montreal: Canadian Federation of Biological Sciences; in press

33. Ge K, Zhai F, Yan $\mathrm{H}$. The dietary and nutrition status of Chinese population. Beijing: People's Medical Publishing House, 1996

34. Sachdev HPS. Nutritional status of children and women in India: recent trends. Bull Nutr Found India 1997;18:3

35. Solon FS. Nutrition related chronic diseases in the Philippines. Makati City, Philippines: Nutrition Center of the Philippines; 1997. Nutrition Center of the Philippines Report Series, vol 2, no 1

36. Ismail MN, Zawaih H, Chee SS, Ng KK. Prevalence of obesity and chronic energy deficiency (CED) in adult Malaysians. Malays J Nutr 1995;1:1-9

37. Hodge AM, Dowse GK, Zimmet PZ. Obesity in Pacific populations. Pacific Health Dialog 1996;3(1):7786

38. Tassie JM, Papoz L, Barny S, Simon D. The CALDIA Study Group: nutritional status in adults in the pluri-ethnic population of New Caledonia. Int J Obes Relat Metab Disord 1997;21:61-6

39. Al-Isa AN. Prevalence of obesity among adult Kuwaitis: a cross-sectional study. Int J Obes Relat Metab Disord 1995;19:431-33

40. Al-Nuaim AR, Al-Rubeaan K, Al-Mazrou'Y, et al. High prevalence of overweight and obesity in Saudi Arabia. Int J Obes Relat Metab Disord 1996;20:54752

41. Khorshid A, Galal Osman M. National Agricultural Research Project. September 1995. Final Technical Report. Development of Food Consumption Monitoring System for Egypt, Oct 1, 1992-Aug 31, 1995

42. Direchon de la Statistique. Consommation et Dipueses des menages 1984/85 Vol 6: situation nutritionnelle de la population du Maroc Ministere de Affaire economique et Sociale. Rabat, Morocco, 1992

43. Jooste PL, Steenkamp HJ, Benade AJS, Rossouw $\mathrm{JE}$. Prevalence of overweight and obesity and its relation to coronary heart disease in the CORIS study. S Afr Med J 1988;74:101-4

44. Steyn K, Fourie J, Rossouw JE, et al. Anthropometric profile of the coloured population of the Cape Peninsula. S Afr Med J 1990;78:68-72

45. Hodge AM, Dowse GK, Gareeboo H, et al. Incidence, increasing prevalence, and predictors of change in obesity and fat distribution over 5 years in the rapidly developing population of Mauritius. Int $\mathrm{J}$ Obes Relat Metab Disord 1996;20:137-46

46. Forrester T, Wilks $R$, Bennett $F$, et al. Obesity in the Caribbean. In: Chadwick DJ, Cardew G, eds. The origins and consequences of obesity. Chichester, England: Wiley, 1996;17-31.

47. Bourne LT, Walker ARP. The nutrition transition in the
Republic of South Africa. In: Proceedings of the international Congress of Nutrition. Montreal: Canadian Federation of Biological Sciences; in press

48. Monteiro, Carlos A. The changing nature of nutritional disorders in the developing countries: the case of Brazil. Proceedings of the International Congress of Nutrition. Montreal: Canadian Federation of Biological Sciences; in press

49. Ge K, Weisell R, Guo S, et al. The body mass index of Chinese adults in the 1980s. Eur J Clin Nutr 1994;48(Suppl 3):S148-54

50. Al-Isa AN. Changes in body mass index (BMI) and prevalence of obesity among Kuwaitis, 1980-1994. Int J Obes Relat Metab Disord 1997;21:1093-9

51. Popkin BM, Paeratakul S, Ge K, Zhai F. Body weight patterns among the Chinese: results from the 1989 and 1991 China Health and Nutrition Surveys. Am J Public Health 1995;85:690-4

52. Hodge AM, Dowse GK, Toelupe P, et al. Dramatic increase in the prevalence of obesity in Western Samoa over the 13-year period, 1978-1991. Int J Obes Relat Metab Disord 1994;18:419-28

53. Hodge AM, Dowse GK, Zimmet PZ, Collins VR. Prevalence and secular trends in obesity in Pacific and Indian Ocean Island populations. Obes Res 1995;3(Suppl 2):77S-87S

54. Taylor $R$, Badcock J, King $H$, et al. Dietary intake, exercise, obesity and noncommunicable disease in rural and urban populations of three Pacific Island countries. J Am Coll Nutr 1992;11:283-93

55. Brown PJ, Konner M. An anthropological perspective on obesity. Ann N Y Acad Sci 1987;499:29-46

56. Popkin BM. Population and development overview: the nutrition transition. In: Sadler M, Caballero B, Strain S, eds. The encyclopedia of human nutrition. London: Academic Press, 1998; in press

57. Drewnowski A, Popkin BM. The nutrition transition: new trends in the global diet. Nutr Rev 1997;55:3143

58. Popkin BM. The nutrition transition in low-income countries: an emerging crisis. Nutr Rev 1994;52:28598

59. Popkin BM, Paeratakul S, Zhai F, Ge K. Dietary and environmental correlates of obesity in a population study in China. Obes Res 1995;3(Suppl 2):135S$43 S$

60. Popkin BM, Bisgrove, EZ. Urbanization and nutrition in low-income countries. Food Nutr Bull 1988;10(1): 3-23

61. Zimmet PZ, McCarty DJ, de Courten MP. The global epidemiology of non-insulin dependent diabetes mellitus and the metabolic syndrome. J Diabetes Complications 1997;11:60-8

62. Seidell JC. Obesity in Europe. Obes Res 1995;3(2): 89S-93S 